\title{
MYSIDAE OF SHALLOW WATER IN TANABE BAY
}

AUTHOR(S):

Valbonesi, Alessandro; Murano, Masaaki

CITATION:

Valbonesi, Alessandro ...[et al]. MYSIDAE OF SHALLOW WATER IN TANABE BAY. PUBLICATIONS OF THE SETO MARINE BIOLOGICAL LABORATORY 1980, 25(1-4): 211-226

ISSUE DATE:

1980-02-29

URL:

http://hdl.handle.net/2433/175984

RIGHT: 


\title{
MYSIDAE OF SHALLOW WATER IN TANABE BAY ${ }^{1)}$
}

\author{
Alessandro VALBONESI ${ }^{2)}$ \\ Seto Marine Biological Laboratory \\ and \\ MASAAKI MURANO \\ Tokyo University of Fisheries
}

With Text-figures $1-8$

\begin{abstract}
Plankton collections obtained during a study on vertical distribution and migration of planktonic animals in the shallow nearshore water of Tanabe Bay contained various forms of mysids. By closer examination, some of them were revealed to be new species that had not been reported. The present collecting spots are only about $450 \mathrm{~m}$ off the northen shore of the Seto Marine Biological Laboratory and are about $7 \mathrm{~m}$ deep at low tide. These mysids were mostly collected from the water layers within $0.3 \mathrm{~m}$ from the sandy sea floor in daytime by the bottom plankton net and/or in the upper water layers at night by vertical hauling. In regard to mysids in Tanabe Bay, Bieri and Tokioka (1968) have reported 4 species, Siriella trispina, Gastrosaccus kojimaensis, Hypererythrops spinifera and Proneomysis tenuicauda, in their paper on an epibenthos sampler, Dragonet II. However, these species were not taken in the present collections excepting $H$. spinifera. In the present paper, all the species of mysid collected are accounted for and the new species and the forms newly found are described. Measurements of total length were taken from the apex of rostrum to the tip of telson.
\end{abstract}

Acknowledgments. Our gratitude is also due to the staff of the Seto Marine Biological Laboratory for their assistance in collecting. Prof. T. H. Carefoot of the British Columbia University, who was staying at the Seto Marine Biological Laboratory, kindly read the manuscripts, to whom we are also grateful. One of the authors, A. Valbonesi, thanks to Prof. Eiji Harada of the University of Kyoto for his valuable advice, encouragement and whose help made the present work possible; he expresses his sincere gratitude to the Japan Ministry of Education for giving him the opportunity to study at Seto Marine Biological Laboratory.

1) Contributions from the Seto Marine Biological Laboratory, No. 657.

2) Home address: Via N. Farnesi n², 55100 Lucca, Italy.

Publ. Seto Mar. Biol. Lab., XXV (1/4), 211-226, 1980.

(Article 14) 


\section{Siriella lingvura $\mathrm{Ii}$}

(Text-fig. 1)

Siriella lingvura $\mathrm{Ii}, 1964$ : 78-82

Material. One adult male collected in May 1978. Body length: $6.5 \mathrm{~mm}$.

Remarks. The present species was established by Ii, based on 2 ovigerous females. The adult male found in this collection fully confirms its taxonomic position within the

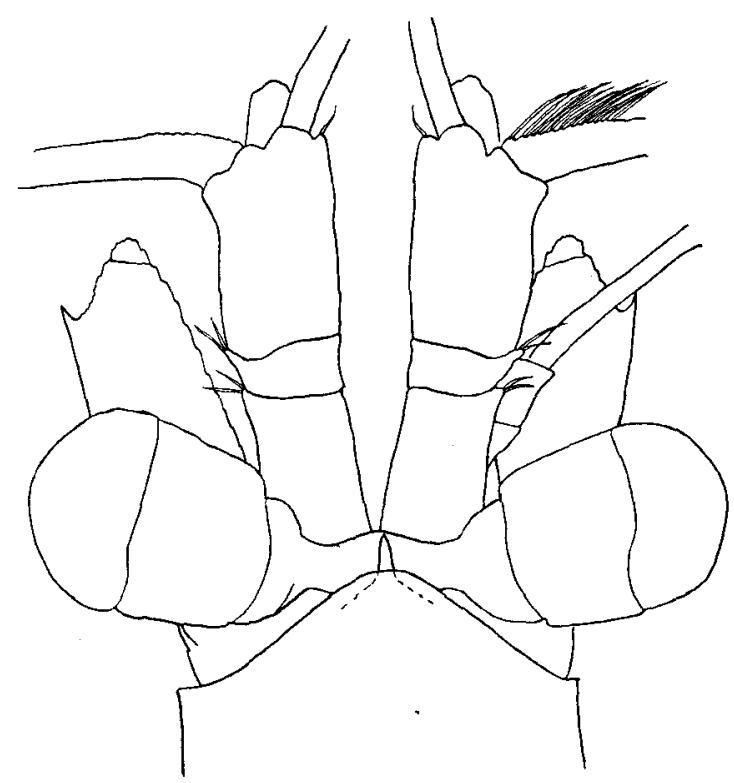

A

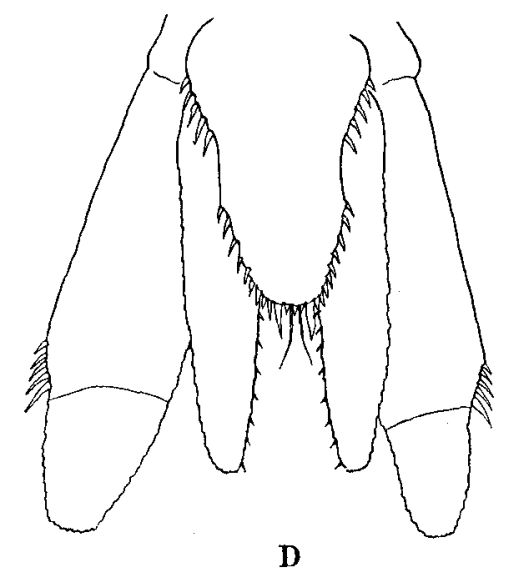

Fig. 1. Siriella lingvura Ii: A, anterior end of adult male $(\times 75) ; \mathrm{B}$, eighth thoracic limb of male and penis $(\times 75) ; C$, penis $(\times 150) ; D$, telson and uropods of male $(\times 75)$.
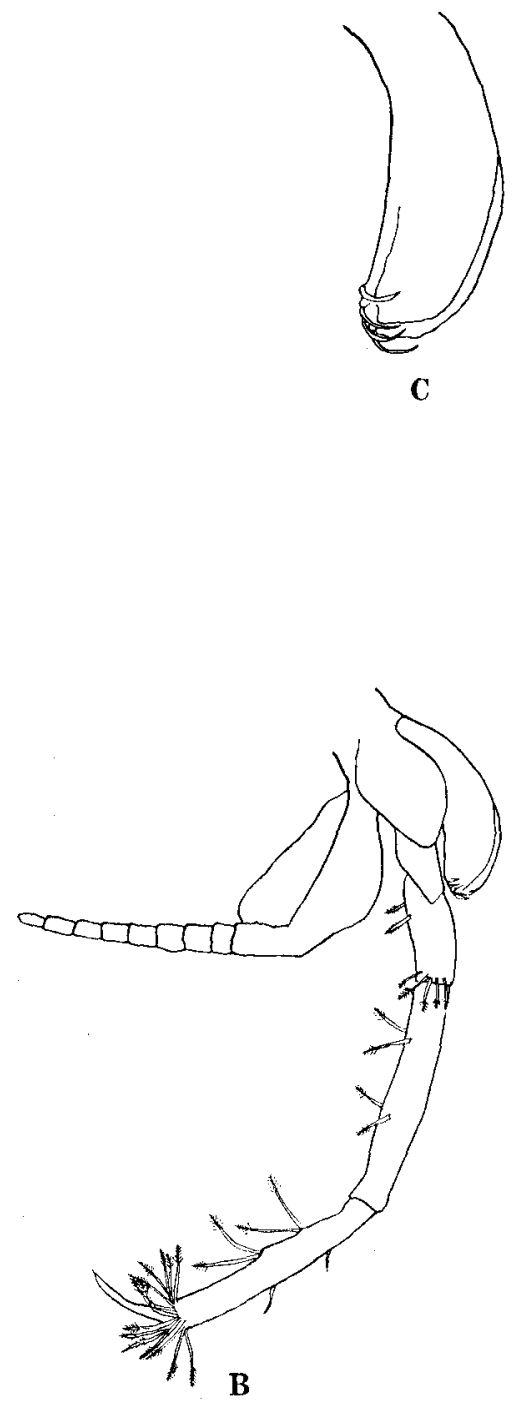

B 
Thompsoni group, Thompsoni sub-group. Except obviously recognizable typical male attributes, like a well developed appendice masculina and the presence of a penis at the base of the exopod of the eighth thoracic limb (Text-fig. I, B \& C), the only differences found between the present male specimen and the female described by Ii are in the antennular peduncle and in the antennal scale. The antennular peduncle in male is not so slender as in female and the third joint is as long as the first one. The antennal scale does not extend further beyond the $2 / 3$ of the third joint of antennular peduncle in male, while it does in female (Text-fig. 1, A).

Ecological note. Only one adult male was found, and this catch in shallow water may be regarded as accidental. This species may probably be a neritic form as reported by Ii.

Distribution. Hitherto known only from Nagatsuro and Tanabe Bay (Japan).

\section{Pseudanchialina inermis Illig}

(Text-fig. 2)

Chlamydopleon inerme Illig, 1906: 209-210.

Pseudanchialina inermis Hansen, 1910: 61 ; Illig, 1930: 422-423; Coifmann, 1936: 31-32; Pillai, 1973: 75-77. Pseudanchialina sibogae Nouvel, 1944: 13; 1959: 222-223; O. Tattersall, 1965: 84-87.

Pseudanchialina erythraea Nouvel, 1944: 13-15; 1959: 223-226; Bacescu, 1975: 45.

Material. Many mature and immature males and females collected in July, August and October 1978. Body length: Largest adult male $2.3 \mathrm{~mm}$, largest adult female $2.2 \mathrm{~mm}$.

Description. Body slender. Carapace large, with a well developed rostral plate; rostral plate lightly covering the basal portion of eyes, somewhat triangular in shape with narrowly rounded apex (Text-fig. 2, A); posterior margin feebly emarginate, leaving only the last thoracic somite uncovered. Eyes well developed, with eyestalk broader than long and bearing spinules on its inner margin. Antennular peduncle three-jointed, with the third and first segments nearly equal in length, spinules present throughout the whole length of its inner margin, appendice masculina rudimentary, inner flagellum considerably slender than outer in both sexes. Antennal scale short, narrow at the base, becoming twice broader at the apex; outer margins slightly concave and bared, ending in a stout spine and extending a little beyond the half of the third antennular peduncle joint; terminal lobe $1 / 9$ of the total length of the scale. Antennal peduncle short, with the proximal joint conspicuously longer than the sum of the two following segments and bearing spinules on both inner and outer margins (Text-fig. 2, B). Pleopods in female all rudimentary. In male first, fourth and fifth pleopods rudimentary. Second male pleopod biramous, extending to about half of the third abdominal somite; endopod reduced to knob-like process; exopod incompletely twojointed, terminal joint very short, 1/4 of basal one, with 2 setae of which inner one is very long, longer than exopod (Text-fig. 2, D). Third male pleopod well developed, extending backward a little beyond the middle of the sixth abdominal somite; endopod reduced to knob-like process; exopod more than $12 / 3$ times as long as basal segment, 
unjointed but there is a weak constriction at $4 / 5$ of length of exopod from its base, ending with 3 subequally long setae (Text-fig. 2, E). Telson $21 / 2$ times longer than broad at the base, lightly cleft being only $1 / 13$ of its total length; lateral margin somewhat concave, armed with 4 spines on distal $3 / 5$, distalmost one being nearly terminal;

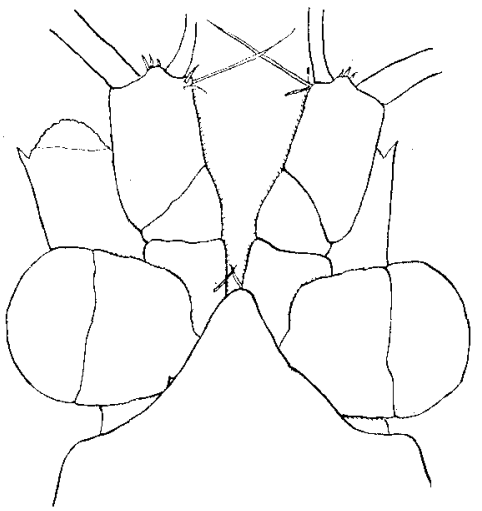

A

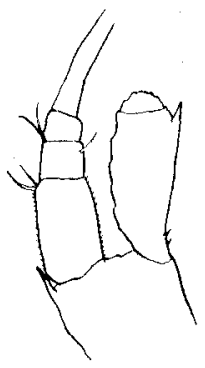

B

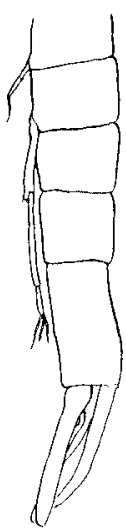

C
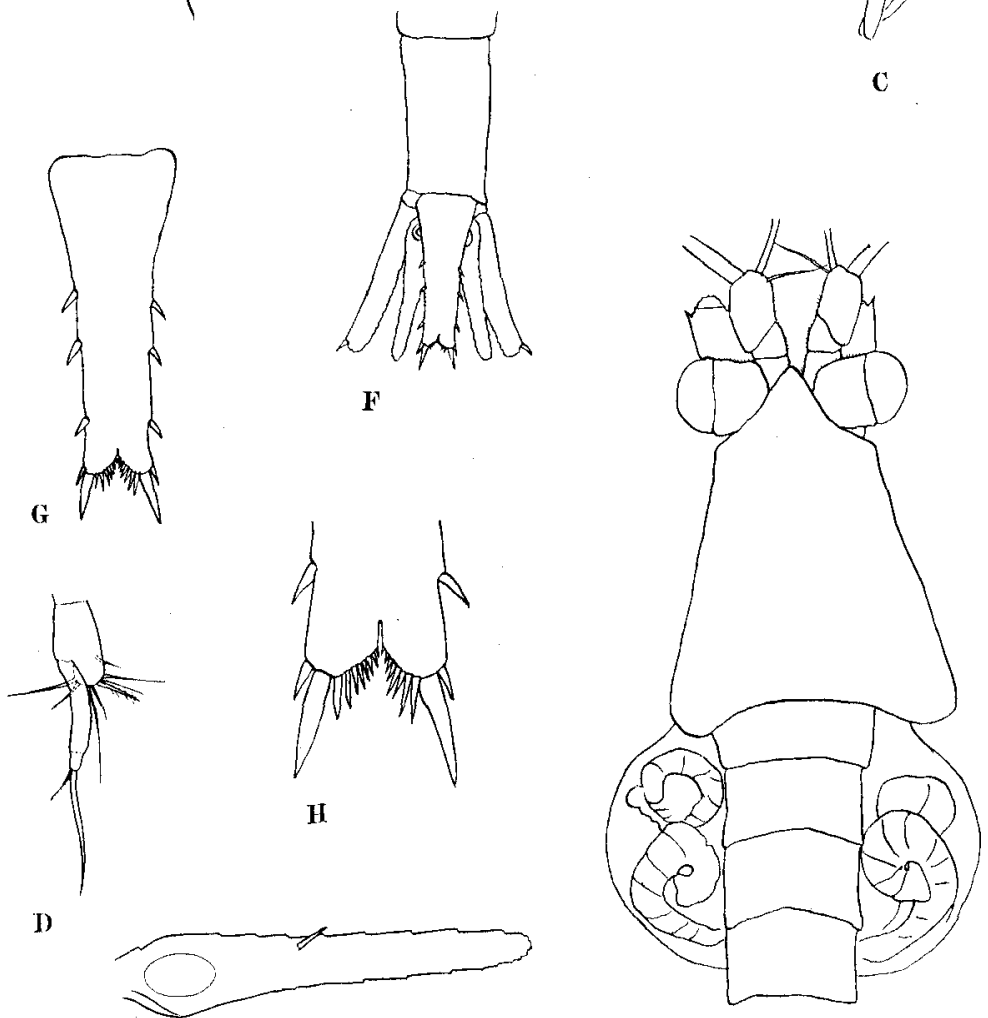

$\mathbf{E}$

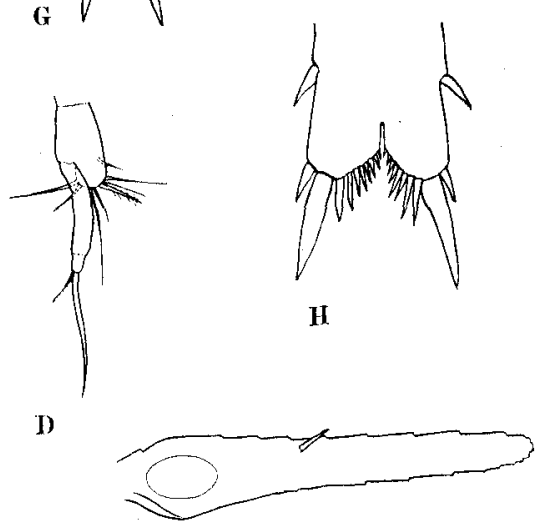

I
L

Fig. 2. Pseudanchialina inermis Illig: A, anterior end of adult male $(\times 150) ; \mathrm{B}$, antennal peduncle and scale of male $(\times 150) ; \mathrm{C}$, lateral view of abdominal region of male $(\times 75) ; \mathrm{D}$, second male pleopod $(\times 144)$; E, third male pleopod $(\times 144) ; \mathrm{F}$, telson and uropods of male $(\times 75)$; $G$, telson of male $(\times 150) ; H$, apical lobes of the same $(\times 300)$; , uropodal endopod of male $(\times 144) ; \mathrm{L}$, dorsal view of adult female bearing embryons $(\times 75)$. 
apical lobe truncate and armed with a single extremely long spine; cleft with a narrow incision on its bottom, armed with 7-8 spines gradually increasing in length from bottom to apex (Text-fig. 2, G \& H). Uropodal exopod, endopod and telson all about the same length; outer margin of exopod smooth and ending with a stout spine (Textfig. 2, F); endopod armed with a single moderate spine on ventral surface at middle of its length (Text-fig. 2, I).

Remarks. In 1973 Pillai discovered that $P$. sibogae, named by Nouvel in 1944 for the specimens collected by Siboga Expedition, is a synonym of $P$. inermis after the examination of hundreds of specimens of both $P$. pusilla and $P$. inermis obtained during the International Indian Ocean Expedition. Moreover, he expressed his opinion that $P$. erythraea is the same as $P$. inermis, because a difference is found only in the number of spines on the lateral margin of the telson, 3-4 in $P$. erythraea and 4-5 in $P$. inermis. We are of the same opinion. The present Japanese specimens are allied with the descriptions and figures of Hansen (1910) and Pillai (1973), but small differences are found as follows. 1) In the present specimens the number of spines on the lateral margin of telson is 4, while it is 5 in Hansen's specimens. 2) Apex of rostral plate is more slender in the present specimens than in Pillai's specimens. 3) In the present specimens the exopod of the second male pleopod is curved outwardly and is imperfectly divided into two segments, while in Pillai's specimens it is straight and one-jointed. Pillai obtained his specimens probably from the surface layer of offshore waters of the tropical Indian Ocean, whereas the present specimens, as well as Hansen's ones, were collected from coastal waters. In the surrounding seas of Japan the species has never been collected from offshore waters. It is very interesting that a single species has two habitats, offshore and coastal.

Distribution. Up to date, the species has been recorded from the tropical Indian Ocean, Timor, Malacca Strait, Red Sea and Suez Canal and from Tanzania (as $P$. erythraea). The present occurrence from Japan, therefore, is the first record in the western North Pacific, and considerably extends the range of distribution of this species.

\section{Hypererythrops spinifera Hansen}

Hypererythrops spinifera Hansen, 1910:62-63; W. Tattersall, 1922: 464-466; 1936: 150; Pillai, 1964: 24-25; Ii, 1964: 328-330; O. Tattersall, 1965: 89-90.

Material. One near-adult male collected in July 1978. Body length: $5.5 \mathrm{~mm}$.

Ecological note. This species is probably a neritic form.

Distribution. East Indies; Andaman Island; Great Barrier Reef; South India; Malacca Strait; southern Japan.

\section{Doxomysis rinkaiensis sp. nov.}

(Text-figs. $3 \& 4$ )

Material. Many mature and immature males and females collected in July and August 1978. Body length: Largest adult male $7.5 \mathrm{~mm}$, largest adult female $6.8 \mathrm{~mm}$. 


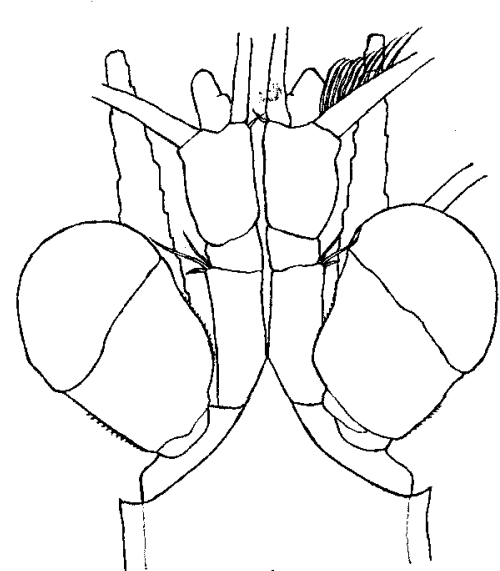

A

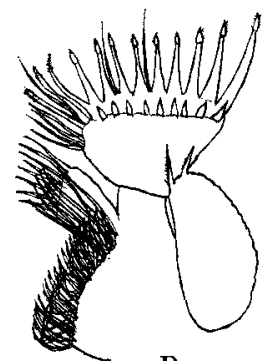

D
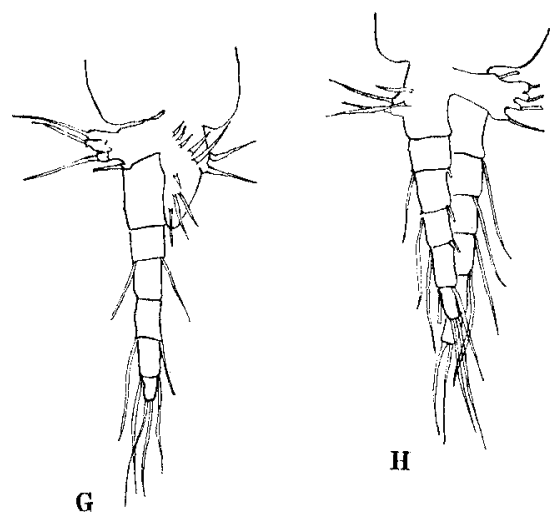
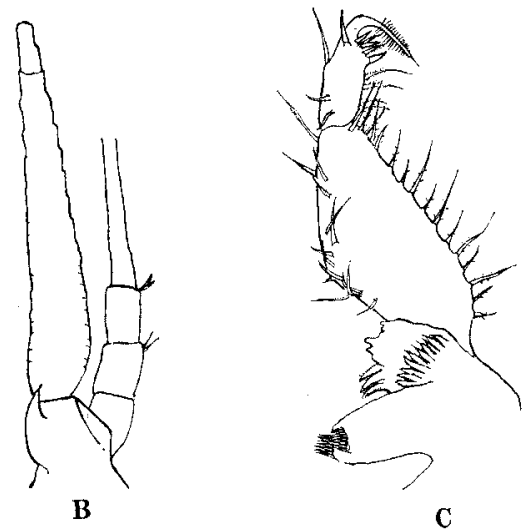

C

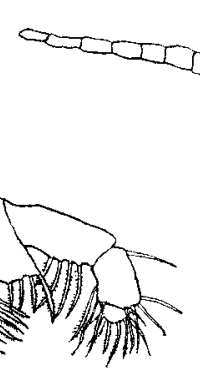

$\mathbf{E}$
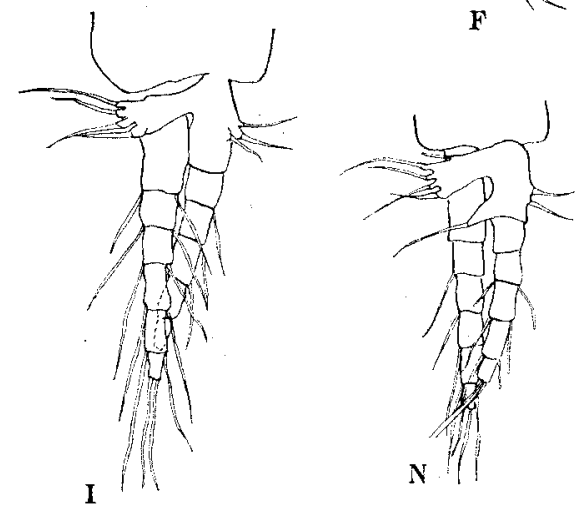

Fig. 3. Doxomysis rinkaiensis sp. nov.: A, anterior end of adult male $(\times 75) ; \mathrm{B}$, antennal peduncle and scale of male $(\times 75) ; \mathrm{C}$, mandible and palp of male $(\times 150) ; \mathrm{D}$, second maxilla of male $(\times 150) ; \mathrm{E}$, endopod of first male thoracic limb $(\times 75) ; \mathrm{F}$, sixth male thoracic $\operatorname{limb}(\times 75) ; G$, first male pleopod $(\times 150) ; \mathrm{H}$, second male pleopod $(\times 150)$; I, third male pleopod $(\times 150)$; $\mathrm{N}$, fifth male pleopod $(\times 150)$. 
Description. Carapace short, leaving dorsally the last two thoracic somites exposed; front margin produced into a triangular rostral plate with pointed apex, lateral margins of rostrum distinctly concave, leaving eyestalks uncovered; antero-lateral corners of carapace somewhat pointed (Text-fig. 3, A). Eyes large, elongated, extending to the middle of the third joint of the antennular peduncle, about $11 / 2$ times as long as broad; inner and outer surface of the stalk with spinules; cornea occupying a little more than distal $1 / 3$ of the eye and slightly broader than the stalk, pigments dark reddish brown. Antennular peduncle in male with first segment longer than third, second segment shortest, inner flagellum normal and slender and appendice masculina well developed.
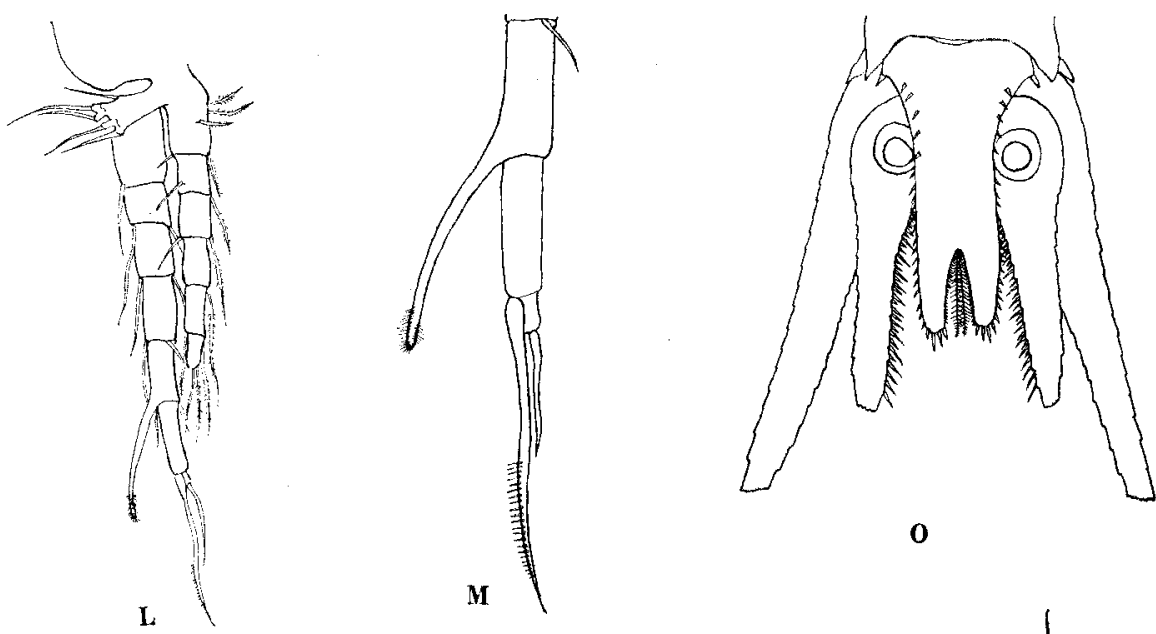

$\mathbf{0}$

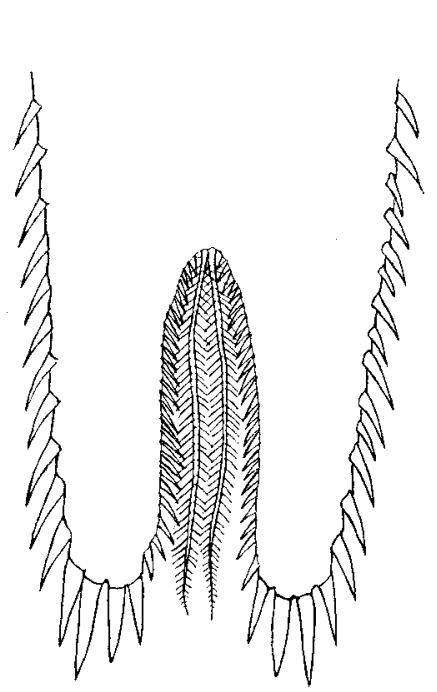

$\mathbf{Q}$

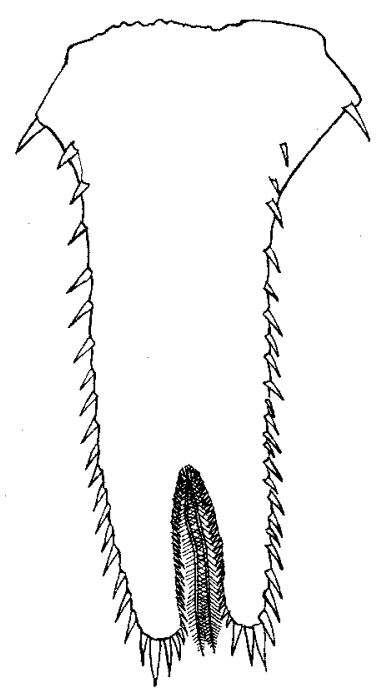

$\mathbf{P}$

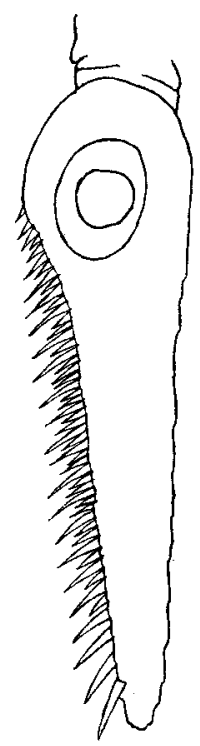

$\mathbf{R}$

Fig. 4. Doxomysis rinkaiensis sp. nov.: $\mathrm{L}$, fourth male pleopod $(\times 150) ; \mathrm{M}$, distal end of exopod of the same $(\times 300) ; O$, telson and uropods of male $(\times 75)$; , telson of nale $(\times 150)$ : Q, distal end of the same $(\times 300) ; R$, uropodal endopod of male $(\times 150)$. 
In the female the peduncle slightly more slender than in the male and the first segment $11 / 2$ times longer than the third. Antennal peduncle short, extending somewhat beyond the middle of the first joint of the antennular peduncle, composed of three equal joints. Antennal scale elongated and narrow, $91 / 2$ times as long as broad at the base, extending for about $1 / 4$ of its length beyond the distal end of the antennular peduncle, with terminal lobe being about $1 / 7$ of total length and 3 times as long as broad; sympod with a stout, prominent spine on outer distal margin (Text-fig. 3, B). Mandible with second segment of palp having a very convex inner margin (Text-fig. 3, G). Maxilla allied to that of the genus with terminal joint of palp of second maxilla more broad than long (Text-fig. 3, D). Endopod of first thoracic limb with well developed masticatory lobes on the basis, ischium and merus (Text-fig. 3, E). Endopod of third to eighth thoracic limbs with carpus separated from propodus by an oblique articulation; propodus divided into two subjoints of which the proximal is the shorter and the distal is nearly as long as the carpus (Text-fig. 3, F). First pleopod of male with rudimental endopod, not distinctly divided from protopod, unjointed, about 3 times as long as broad at the base (Text-fig. 3, G). Second, third and fifth pleopods with both exo- and endopod six-jointed (Text-fig. 3, H, I \& N). Fourth pleopod with a seven-jointed exopod and a six-jointed endopod; a long curved spiniform process arising from the outer distal corner of the fifth joint of exopod and extending a little far beyond the end of the seventh joint, setose and round at its tip; sixth joint bearing at its distal end a long stout seta, which is twice as long as the joint and is armed with a row of spinules on the external side of its distal half; seventh joint very small, about $1 / 4$ of the length of the preceding joint and with a short simple terminal seta (Text-fig. 4, L \& M). Fifth pleopod with a finger-like process on the outer distal margin of the first joint of endopod, besides the usual side lobe (Text-fig. 3, N). Telson cleft and $11 / 4$ times as long as the last abdominal somite, approximately twice as long as maximum breadth near the base; lateral margins sharply narrowing proximally but of nearly similar breadth for the most part, armed with 18-22 (average 20) spines and distal margin of each lobe with 3-4 rather stout spines; terminal cleft deep, about $1 / 3$ the length of the telson, with 24-26 small spines and a pair of long plumose setae extending from the bottom of the cleft over its whole length (Text-fig. 4, O, P \& Q). Endopod of uropod $11 / 4$ times longer than the telson, inner margin armed with a row of 48-50 stout spines alternating in size (Text-fig. 4, R). Exopod of uropod about 1 1/2 times as long as the telson.

Type-series. Holotype, SMBL type-315; allotype, SMBL type-315; paratype, SMBL type-316. All deposited at the Seto Marine Biological Laboratory.

Remarks. This genus can be distinguished from the closely related genus Tenagomysis G. M. Thomson by the shape of the terminal joint of the palp of second maxilla which is more broad than long. The characteristic that the lateral margins of the telson are armed with spines throughout their length makes the present specimens closely related to $D$. longiura Pillai, $D$. littoralis Tattersall and $D$. anomala Tattersall. In all these mentioned species, however, the carapace is produced into a very short triangular rostral plate with a blunt or rounded apex, while in the present specimens it is clearly pointed and extends for $1 / 3$ of the length of the first antennular peduncle segment. 
D. longiura differs from the present specimens in having a spiny body, i.e. the spines installed on eyestalks, antennular peduncles and basal part of telson and in addition, in the female, the spines are also arranged in transverse ridges projecting conspicuously on the dorsal side of the body. Also in $D$. longiura, the antennal scale hardly reaches the tip of the antennular peduncle and the spines arming the proximal half of the inner border of the inner uropod, as well as the spines arming the apex of the lobe of the telson of the female, are described by Pillai as blunt, whereas they are all pointed in the present specimens. In the original description of $D$. littoralis there is no mention of the fourth pleopod of the male but, according to the redescription given by $\mathrm{Ii}$, it has an exopod with an antepenultimate joint without any seta, a penultimate joint bearing a single modified stout seta nearly 3 times as long as the joint and a small ultimate joint about half as long as the preceding joint and furnished with 2 short simple terminal setae. In the present specimens the antepenultimate joint bears a long curved spiniform process, setose and rounded at its tip, a penultimate joint with a modified seta only twice as long as the joint and a very small ultimate joint, only $1 / 4$ of the length of the preceding joint and bearing a short simple terminal seta. The present specimens also differ from $D$. anomala in having many more spines occurring both on the internal margins of the cleft and on the lateral margins of the telson. The new species, Doxomysis rinkaiensis, to which the present specimens are assigned, is thus easily distinguished from the other species of the genus in the combination of three characteristics: telson armed with spines throughout its length; carapace with triangular and pointed rostral plate; fourth pleopod of the male, having a long spiniform process on antepenultimate joint of exopod.

Derivation of the name. The species name is derived from "Rinkai" which is the name recently adopted to designate the place where the Seto Marine Biological Laboratory is situated.

Ecological note. It seemingly is a shallow water form.

Distribution. Hitherto known only from Tanabe Bay.

Parastilomysis secunda sp. nov.

(Text-figs. $5 \& 6$ )

Material. Adult males, nearly adult females, young specimens collected in July and August 1978. Body length: Largest adult male $4.3 \mathrm{~mm}$, largest nearly adult female $4 \mathrm{~mm}$.

Description. Body slender. Carapace very short, posterior margin not emarginate and leaving the last three thoracic somites uncovered, frontal margin protruding into a short triangular rostral plate with round apex, antero-lateral corners round (Textfig. 5, A \& B). Eyes large, nearly as long as broad, cornea occupying half of the eye, spinules present on the proximal half of the eyestalk, pigments reddish-brown. Antennular peduncle in the male with first segment as long as third one bearing a well developed appendice masculina. Antennal peduncle with shorter first joint, second 
and third being nearly twice as long as the first one (Text-fig. 5, C). Antennal scale extending far beyond the end of the third antennular segment and reaching the tip of the sexual appendage in the male, with a terminal lobe 1/9 of the total length of the scale. Mouth parts basically and generally similar to those species of the Tribe (Text-fig. 5, D \& E). First thoracic limb with masticatory lobes on the basis, ischium and merus (Text-fig. 5, F). Third to eighth thoracic limbs with carpus about 5/6 as long as propodus from which it is divided by an oblique articulation; propodus divided into two subjoints of nearly equal length (Text-fig. 5, G \& H). First, second and fifth male pleopods uniramous and composed of a short unjointed endopod bearing a short

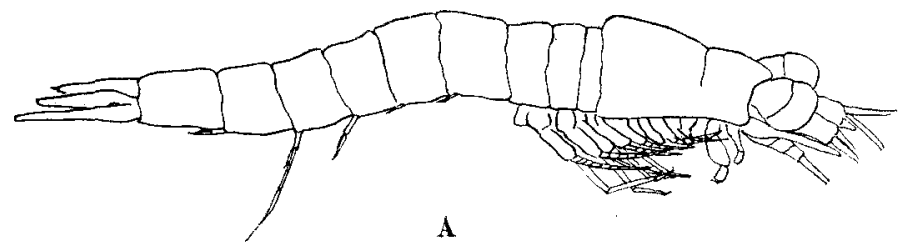

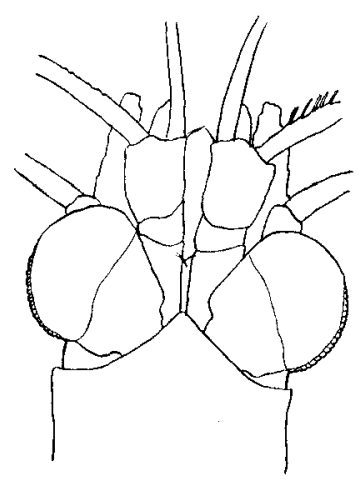

B

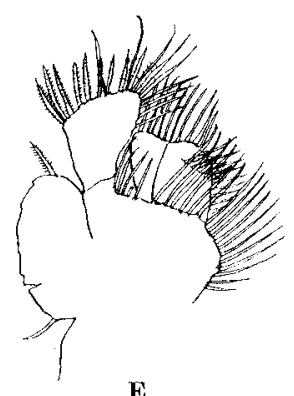

$\mathbf{E}$
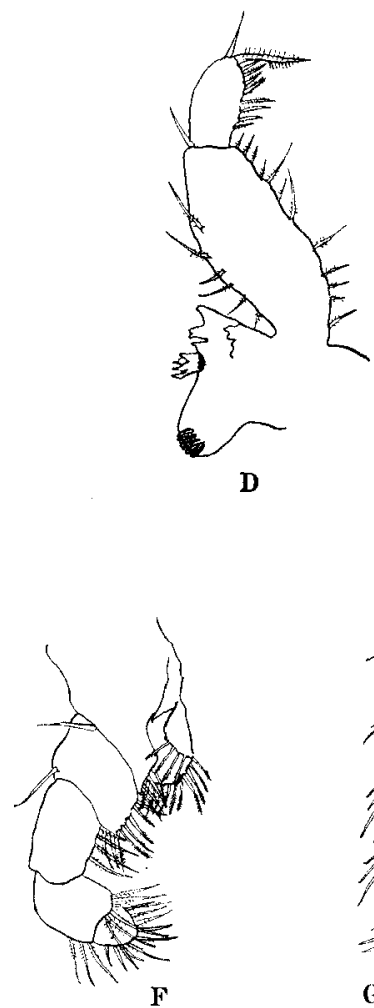

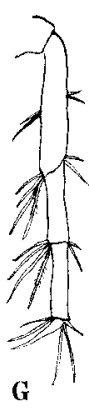

G
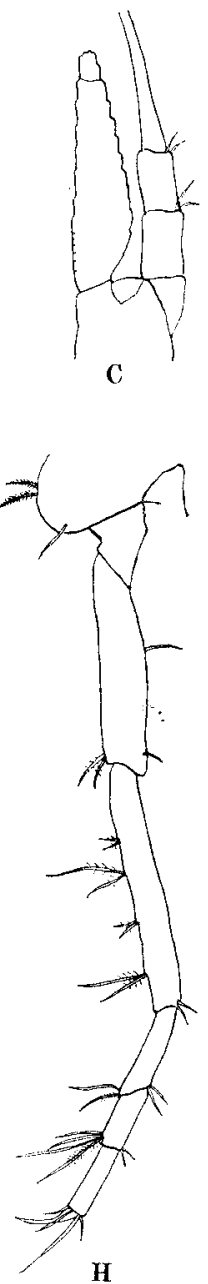

Fig. 5. Parastilomysis secunda sp. nov.: A, adult male from lateral aspect $(\times 30) ; \mathrm{B}$, anterior end of male $(\times 75) ; \mathrm{C}$, antennal peduncle and scale of male $(\times 75) ; \mathrm{D}$, mandible and palp of male $(\times 150)$; E, second maxilla of male $(\times 150) ; \mathrm{F}$, endopod of first male thoracic limb $(\times 150) ; \mathrm{G}$, distal end of endopod of fourth male thoracic limb $(\times 150) ; \mathrm{H}$, endopod of sixth male thoracic limb $(\times 150)$. 
side lobe (Text-fig. 6, I). Third male pleopod biramous; endopod 2/3 times as long as exopod, unjointed, furnished with 2 terminal setae, the outer very long and the inner about half as long as the outer and a row of 5-6 long setae on the ventral surface starting just below the side lobe; exopod four-jointed, extending not quite as far as the proximal margin of the fifth abdominal somite, with first segment elongated, about half as long as the total length, while the last joint is tipped with 2 terminal setae, the outer $11 / 2$ times as long as the inner (Text-fig. 6, L). Fourth male pleopod biramous with an unjointed endopod like the preceding one but only $3 / 7$ as long as exopod; exopod four-
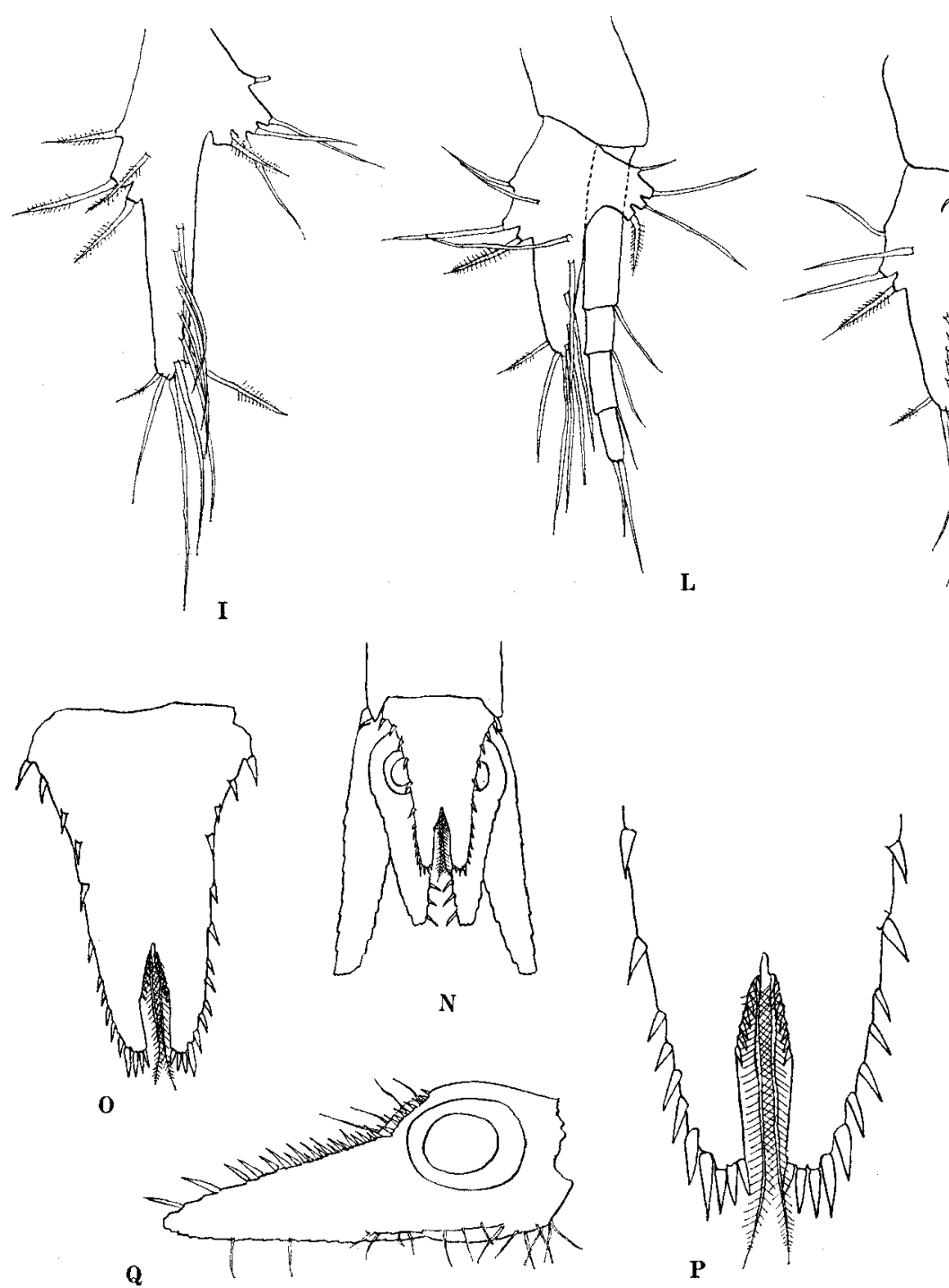

Fig. 6. Parastilomysis secunda sp. nov.: I, second male pleopod $(\times 300)$; L, third male pleopod $(\times 300) ; \mathrm{M}$, fourth male pleopod $(\times 300) ; \mathrm{N}$, telson and uropods of male $(\times 75) ; \mathrm{O}$, telson of male $(\times 150) ; P$, distal end of the same $(\times 300) ; Q$, uropodal endopod of male $(\times 150)$. 
jointed, extending backwards to the end of the sixth abdominal somite, first segment as long as fourth, second shortest, third $2 / 3$ as long as fourth, ultimate segment bearing 2 distinctive processes, inner very short, knob-like with a short seta at apex, outer very long, about $6 / 7$ of the total length, naked on the proximal half, armed with short spines on one side of the second half but again naked at the top (Text-fig. 6, M). Sixth abdominal somite as long as fifth. Telson $11 / 5$ times as long as last abdominal somite, with a deep terminal cleft for $1 / 3$ of its length; lateral margins armed with 12 spines, of which those at the anterior end and at the postero-lateral corners are stronger; apical lobes truncate and armed with 3 spines decreasing in size from outer to inner; cleft with a narrow incision on its bottom bearing a long plumose seta extending from each side of the incision out of the cleft posteriorly for $1 / 3$ of its length, armed with 7 short spines on proximal half of inner margins of the cleft (Text-fig. 6, N, O \& P). Uropodous endopod less than $11 / 3$ times as long as the telson, inner margin armed with a row of 29 spines posterior to statocyst and alternating in size (Text-fig. 6, Q). Uropodous exopod a little more than $11 / 2$ times as long as the telson.

Type series. Holotype, SMBL type-317; allotype, SMBL type-317; paratype, SMBL type-318. All deposited at the Seto Marine Biological Laboratory.

Remarks. Within the Tribe Mysini only three genera, Kainomatomysis, Inusitatomysis and Parastilomysis, have a cleft at the apex of the telson and the cleft is furnished with a pair of plumose setae at its bottom. The present genus Parastilomysis is, however, easily distinguished from the other two genera by the third male pleopod being biramous with a four-jointed exopod and an unjointed endopod. The genus Parastilomysis, established by Ii in 1936, at present contains only one species, $P$. paradoxa. The present specimens differ from the former in the following characters:

1) Frontal margin of carapace protrudent into a short triangular rostral plate, while in $P$. paradoxa is obtusely rounded and furnished with a prominent pseudorostral process below the rostrum. 2) Absence of a prominent spine on the outer distal corner of basal joint from which the scale arises, while is present in P. paradoxa. 3) Third to eighth thoracic limbs with carpus separated from propodus by an oblique articulation; in P. paradoxa this articulation is transverse. 4) In the male the exopod of the fourth pleopod with fourth segment as long as the first and bearing two distinctive processes, inner very short knob-like, outer very long, armed with short spines on one side of the second half. In P. paradoxa the first segment is the longest, the third segment is armed with a single strong spinous seta on the distal outer corner and the fourth segment terminates in two strong spinous setae. 5) Sixth abdominal somite is more elongated in $P$. paradoxa than in P. secunda. 6) Telson shorter than in P. paradoxa in comparison with the breadth and armed with fewer spines. In $P$. secunda there are 12 spines on the lateral margin and 7 spines on the proximal half of the inner margin of the cleft, while in $P$. paradoxa the lateral margin of the telson is armed with 35-40 spines and the inner margin of the cleft with 12 spines throughout its entire length. 7) Urpodous endopod armed with a row of 29 spines alternating in size, whereas in $P$. paradoxa there are about 50 spines not alternating in size.

On the basis of the above mentioned characteristics, the present specimens must refer 
to a new species.

Derivation of the name. The name is derived from the second species of the genus.

Ecological note. It seemingly is a shallow water form.

Distribution. Hitherto known only from Tanabe Bay.

\section{Anisomysis ijimai Nakazawa}

(Text-fig. 7)

Anisomysis ijimai Nakazawa, 1910: 252-253; W. Tattersall, 1921 : 413-414; Ii, 1964: 551-554.

Material. Many mature and immature males and females collected in July and August 1978. Body length: Largest adult male $6.5 \mathrm{~mm}$, largest adult female $6.2 \mathrm{~mm}$.

Remarks. As pointed out by Nakazawa and $\mathrm{Ii}$, this species can be easily distinguished from other species within the genus by 6 spinous knobs on the inner side of the second joint of the mandibular palp (Text-fig. 7, A) and by the lateral constriction of the telson. The present specimens agree with the redescription given by $\mathrm{Ii}$, except for the number of spines on the telson. In the present specimens there are 8 spines on each lateral margin just anterior to the constriction, 3 spines at the constriction, and 20 spines around the terminal round plate (Text-fig. 7, B \& G). Because of this last aspect the present form is regarded to be closer to Nakazawa's form which is reported to bear about 18 spines on the terminal round plate.

Distribution. Hitherto known only from costal water of Japan.
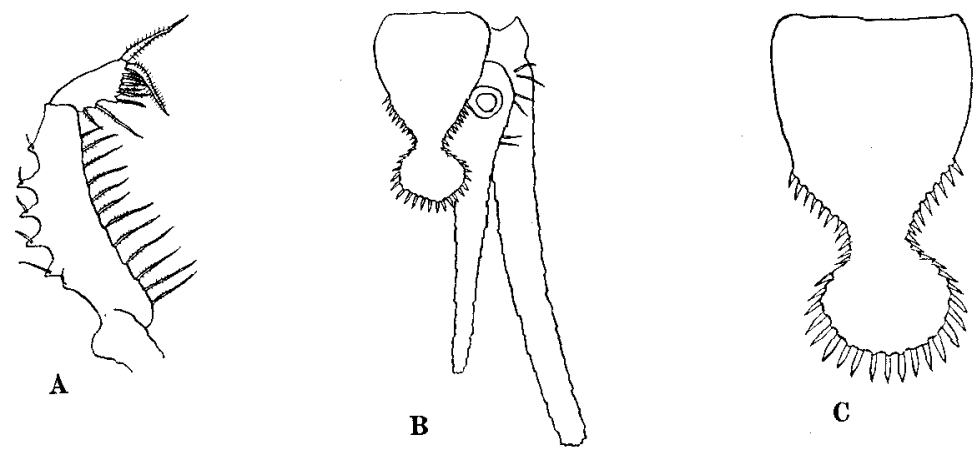

Fig. 7. Anisomysis ïimai Nakazawa: A, mandibular palp of male $(\times 150) ; \mathrm{B}$, telson and uropods of male $(\times 75) ; \mathrm{C}$, telson of male $(\times 150)$.

\section{Anisomysis aikawai $\mathrm{Ii}$}

Anisomysis aikawai Ii, 1964: 559-562.

Material. Many mature and immature males and females collected in July, August and October 1978. Body length: Largest adult male $5.2 \mathrm{~mm}$, largest adult female $5 \mathrm{~mm}$. 
Ecological note. This species is the dominant one in the studied area and is considered as a typical shallow water form.

Distribution. Hitherto known only from Susaki Inlet, Kochi Prefecture, and Tanabe Bay (Japan).

\section{Anisomysis pelewensis Ii}

\section{(Text-fig. 8)}

Anisomysis pelewensis Ii, 1964: 565-567.

Material. Many mature and immature males and females collected in July and August 1978. Body length: Largest adult male $3.5 \mathrm{~mm}$, largest adult female $3.2 \mathrm{~mm}$.

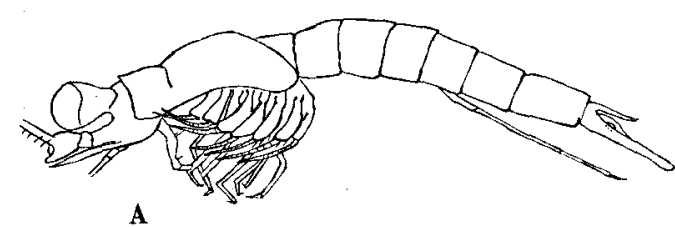

A

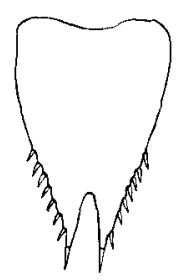

$\mathbf{F}$

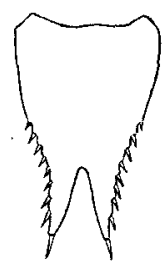

H
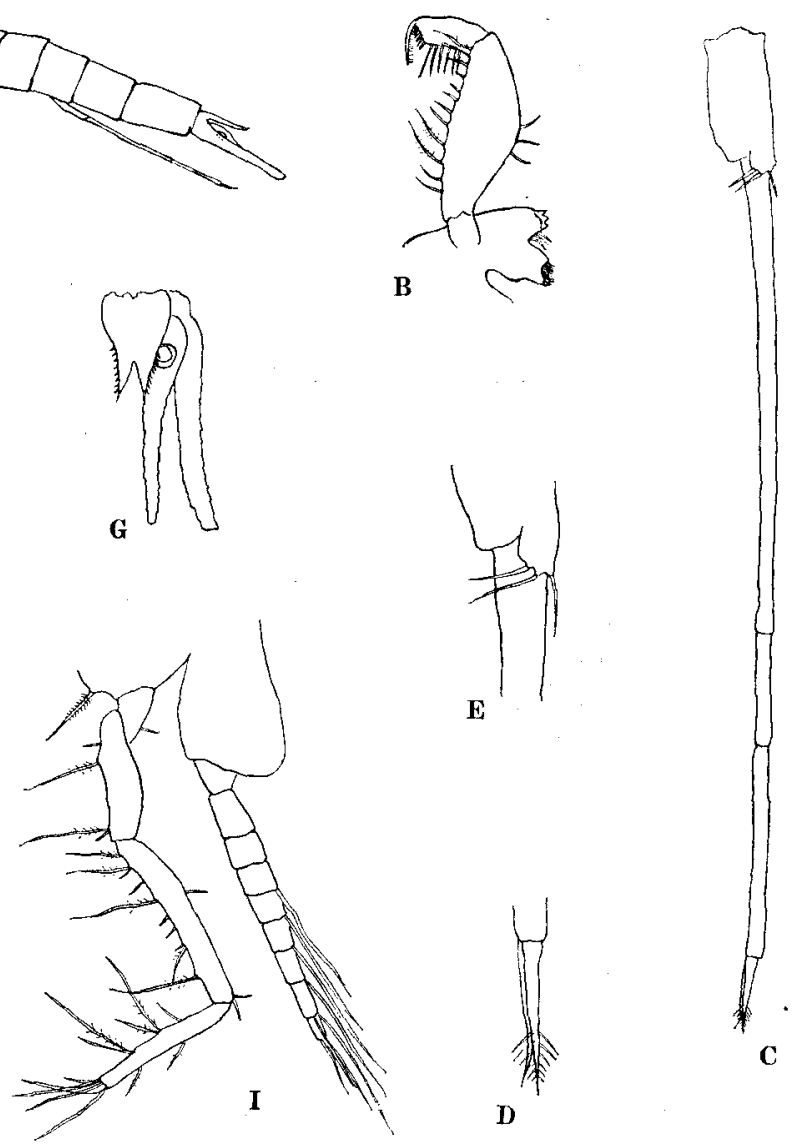

I)

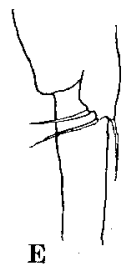

C

Fig. 8. Anisomysis pelewensis Ii: A, adult male from lateral aspects $(\times 30) ; \mathrm{B}$, mandible and palp of male $(\times 150) ; \mathrm{C}$, fourth male pleopod $(\times 150) ; \mathrm{D}$, distal end of exopod of fourth male pleopod $(\times 300) ; E$, endopod of fourth male pleopod $(\times 300) ; F$, telson of male $(\times 150) ; G$, telson and uropods of female $(\times 75) ; \mathrm{H}$, telson of female $(\times 150) ; \mathrm{I}$, eighth thoracic limb of male $(\times 150)$. 
Remarks. The present specimens can be easily identified as Anisomysis pelewensis Ii by the characteristic shape of the telson. However, since the description of this species was based only on one adult female and two young males, some different characteristics mainly occurring in the adult male are as follows: in the adult male the appendice masculina is well developed. The fourth pleopod extends a little beyond the end of the telson (Text-fig. 8, A); exopod elongated and three-jointed, the first segment 4 times as long as the second, the third segment about $11 / 2$ times as long as the second and terminating in 2 short setae, equal in length, the outer slender and naked, the inner thicker and plumose in the distal $1 / 3$ (Text-fig. 8, G \& D); endopod very small and not well divided from protopod, unjointed, almost as long as broad and armed with 3 delicate setae (Text-fig. 8, E). Telson about 2/3 of the sixth abdominal somite in length, only $11 / 2$ times as long as broad at the base; distal cleft deep, about $1 / 3$ of the length of the telson. Lateral margins of the telson not concave but rather convex, so that the narrowest part is at the tip, being about $1 / 3$ of the base in breadth, and armed on posterior half with 7 spines (Text-fig. 8, F). In Ii's specimens the telson is $21 / 2$ times as long as broad at the base, lateral margins distinctly concave, being at the distal end only a little narrower than at the base and bearing 5 spines. The telson of an adult female of the present specimens also has the lateral margins which are slightly concave and armed with 7 to 8 spines, but is still twice as narrow at the end as at the base (Text-fig. 8, G \& H). Another slight difference is that the second segment of the mandibular palp broadens at the middle, being more than twice as broad as the ends (Text-fig, 8. B).

Distribution. In the past the species was only recorded from Iwayama Bay, Palau Islands (about $8^{\circ} \mathrm{N}, 135^{\circ} \mathrm{E}$ ). Its presence in Tanabe Bay is the first record from Japan.

\section{Riassunto}

Nel presente lavoro vengono trattate otto specie di Misidacei rinvenute nelle acque costiere della Baia di Tanabe, delle quali due rappresentano nuove specie non segnalate fino ad oggi. Doxomysis rinkaiensis sp. nov. differisce dalle restanti tre specie del genere in tre principali caratteristiche: struttura del quarto pleopodo del maschio, telson fornito di spine lungo tutta la lunghezza dei suoi margini laterali, carapace che si produce in un rostro appuntito. Parastilomysis secunda sp. nov. si distingue dall'unica specie del genere per la forma del telson e la struttura del quarto pleopodo del maschio. Viene inoltre data ridescrizione di Siriella longvura Ii ed Anisomysis pelewensis Ii le cui precedenti descrizioni erano basate su forme giovanili e/o sul solo ritrovamento di femmine adulte. Interessante e infine la segnalazione di un esemplare di Pseudanchialina inermis Illig che rappresenta il primo ritrovamento nelle acque occidentali del Nord Pacifico ed estende notevolmente il raggio di distribuzione di questa specie. 


\section{REFERENCES}

Bacescu, M. 1975. Contributions to the knowledge of the mysid (Crustacea) from Tanzanian waters. Univ. Sci. J. (Dar. Univ.), 1: 39-61.

Bieri, R. and T. Tokioka 1968. Dragonet II, an opening-closing quantitative trawl for the study of microvertical distribution of zooplankton and meio-epibenthos. Publ. Seto Mar. Biol. Lab., 15: 373-390.

Coifmann, I. 1936. I misidacei del Mar Rosso. Studio del materiale raccolto dal Prof. L. Sanzo durante la campagna idrografica della R. Nave Ammiraglio Magnaghi (1923-1924). Mem. R. Comitato Talassografico Ital., No. 233: 1-52.

Hansen, H.J. 1910. The Schizopoda of the Siboga Expedition: Siboga Exped., 37: 1-120.

Ii, N. 1964. Fauna Japonica, Mysidae. Biogeogr. Soc. Jap., 610 pp.

Illig, G. 1906. Bericht über die neunen Schizopoden-gattungen und -arten der deutschen TiefseeExpedition 1898-1899. Zool. Anz., 30: 194-211.

Illig, G. 1930. Die Schizopoden der deutschen Tiefsee-Expedition. Rep. Valdivia Exped., 22: 397625.

Nakazawa, K. 1910. Notes of Japanese Schizopoda. Annot. Zool. Japan., 7: 247-261.

Nouvel, H. 1944. Diagnoses de Mysidaces nouveaux de la Mer Rouge et du Golfe d'Aden. Bull. Soc. Hist. nat. Toulouse, 79: 255-269.

Nouvel, H. 1959. Mysidacea. Mission Robert Ph. Dollfus en Egypte. Res. sci., 3e partie: 195-240.

Pillai, N.K. 1964. Report on the Mysidacea in the collections of the Central Marine Fisheries Research Institute, Mandapam Camp, South India-I. J. mar. biol. Ass. India, 6: 1-41.

Pillai, N.K. 1973. Mysidacea of the Indian Ocean. I.O.B.S., Handbook, 4: 1-125.

Tattersall, O.S. 1965. Report on a small collection of Mysidacea from the northern region of the Malacca Strait. J. Zool., London, 147: 75-98.

Tattersall, W.M. 1921. Mysidacea, Tanaidacea, and Isopoda. Pt. 7. In Annandale, N. (ed.), Zoological result of a tour in the Far East. Mem. Asiatic Soc. Bengal, 6: 403-433.

Tattersall, W.M. 1922. Indian Mysidacea. Rec. Ind. Mus., 24: 445-504.

Tattersall, W.M. 1936. Mysidacea and Euphausiacea. Sci. Rep. Gt. Barrier Reef Expedition, 5: 143176. 